\title{
Etos Kerja Profesionalisme Dalam Penyelenggaraan Birokrasi Pemerintahan
}

\author{
Ridho Harta \\ Bambang Agus Diana
}

\begin{abstract}
ABSTRAK
Masyarakat yang maju adalah masyarakat yang memapu menghargai tatanan dalam berbagai kegiatan dalam kehidupannya, begitu juga dalam melaksanakan pekerjaan sehari-hari seperti memiliki Nilai-nilai etika yang dikaitkan dengan etos kerja seperti rajin, bekerja, keras, berdisplin tinggi, menahan diri, ulet, tekun dan nilai-nilai etika lainnya bisa juga ditemukan pada masyarakat dan bangsa lain.

Pada era otonomi saat ini, yang dibarengi dengan pesatnya kemajuan ilmu pengetahuan Birokrasi Pemerintah, diperlukan pondasi-pondasi penyelenggaraan negara yang kokoh sebagai penyangganya. Untuk melaksanakan fungsi yang semakin luas dan kompleks, maka sektor pemerintah tentunya memerlukan berbagai sumber daya yang memadai. Bersamaan dengan proses perluasan fungsi dan peranan aparatur pemerintah, telah terjadi pula "harapan/tuntutan" yang semakin meningkat dari kalangan masyarakat (publik) terutama yang berkaitan dengan etos kerjanya. Etos kerja merupakan nilai dasar moralitas yang dapat memberi dorongan mental maupun spiritual bagi seorang aparat birokrasi untuk dapat berprestasi dalam menjalankan profesinya.
\end{abstract}

Kata kunci: Etos kerja, sumber daya manusia, pemerintahan.

\section{A. Pendahuluan}

Pada dasarnya pembangunan sumber daya manusia (SDM) khususnya sektor pemerintah, merupakan kunci pengamanan masa depan bangsa. Karena bagaimanapun potensi perkembangan ekonomi suatu negara sangat dipengaruhi oleh SDM dengan kualitas pengetahuan dan keterampilannya, pandangan budayanya, sikapnya terhadap kerja, serta semangat juangnya dalam meningkatkan kemandirian. Dengan kata lain, adanya etos kerja yang mandiri dan profesional merupakan suatu conditio sine quanon bagi terselenggaranya pemerintah yang efektif dan efisien. selain itu Nilai-nilai etika yang dikaitkan dengan etos kerja seperti rajin, bekerja, keras, berdisplin tinggi, menahan diri, ulet, tekun dan nilai-nilai etika lainnya bisa sangatlah menunjang agar penyelenggaraan pemerinatahan dapat berjalan dengan baik untuk terciptanya good governance. Untuk menciptakan aparatur pemerintahan yang memliki etos kerja yang tinggi, maka pemerintah sedini mungkin mengusahakan profesionalisme aparaturnya. Walaupun harus diakui bahwa profesionalisme aparatur bukan satu-satunya jalan untuk meningkatkan kinerja birokrasi, karena masih ada alternatif lain, misalnya dengan menciptakan sistem dan prosedur kerja yang efisien. Namun adanya aparatur yang profesional tidak dapat dihindari oleh pemerintah yang bertanggung jawab. 
Bermacam-macam pelayanan terhadap masyarakat, mulai dari pemberian izin-izin (lisensi) sampai kepada penyediaan jasa-jasa, bahkan distribusi barang-barang yang mencakup semua aspek kehidupan masyarakat. Hal ini tentunya memerlukan penanganan yang serius dari pemerintah, sebab jika tidak, bukan mustahil pemerintah akan kehilangan kepercayaannya dari masyarakat sebagai pengguna jasa.

\section{B. Pembahasan}

\section{Birokrasi dan Pelayanan Publik}

Birokrasi pelayanan publik pada dasarnya merupakan hal yang utama yang harus dilakukan oleh pemerintah sebagai pelayan masyarakatnya, karena hal itulah merupakan suatu kewajiban yang harus dilakukan pemerintah terhadap rakyatnya dengan memberikan pelayanan sebaik mungkin. melihat pada pengertian dan konteks birokrasi sendiri, di negara manapun akan sama bahwa fungsi utama birokrasi selain memungut pajak dari masyarakat adalah memberikan pelayanan kepada masyarakat. Di dalam penanganan pelayanan kepada masyarakat ini, agar memiliki kualitas pelayanan yang bermutu dan memiliki keunggulan, maka diperlukan aparataparat pemerintah yang handal dan profesional, bersih dan berwibawa yang dilandasi etos kerja yang tinggi.

Pengertian "birokrasi" yang dicetuskan oleh Max weber telah bergeser dari makna sebenarnya. Pengertian birokrasi itu sendiri antara lain sebagai suatu sistem pengelolaan dalam organisasi skala besar seperti organisasi pemerintah, yang ditandai oleh adanya keteraturan, ketertiban, pembagian wewenang dan jalur hirarkhi yang jelas, dan sebagainya. Tetapi pengertian terapannya yang berkembang adalah bahwa birokrasi sebagai suatu sistem dimana kelembagaan, prosedur yang berbelitbelit, dan tata aturan yang ruwet menjadi ciri utamanya. Bahkan menurut Riggs (1985), birokrasi sering dihubungkan dengan prosedur kerja yang panjang dengan peraturannya yang aneh-aneh dan sewenang-wenang. Padahal peranan birokrasi sebenarnya sangat penting, bahkan menjadi salah satu ciri dari masyarakat modern.

Bila kita mengamati secara jujur, apa yang disebutkan oleh Riggs tersebut juga terdapat pada birokrasi negara kita. Pertanyaan etis kembali muncul sehubungan dengan kurangnya perhatian (concern) para aparatur birokrasi terhadap kebutuhan warga negara tersebut. Untuk memperoleh pelayanan yang sederhana saja, pengguna jasa (masyarakat) sering dihadapkan pada kesulitan-kesulitan yang sebenarnya tidak perlu terjadi. Selain itu, rutinitas tugas-tugas pelayanan dan penekanan yang berlebihan kepada pertanggungjawaban formal telah mengakibatkan adanya prosedur yang kaku dan lamban. Para pegawai tidak lagi merasa terpanggil untuk meningkatkan efisiensi dan memperbaiki prosedur kerja, tetapi lebih sering justru menolak adanya perubahan. Etos kerja yang cenderung mempertahankan status quo ini telah menumbuhkan persepsi masyarakat bahwa berhubungan dengan birokrasi berarti berhadapan dengan berbagai prosedur yang berbelit-belit. Bahkan tidak sedikit pemberian pelayanan acapkali ditunggangi oleh kepentingan pribadi dan dijadikan alat komoditas untuk kepentingan pribadi atau kelompok.

Sikap para birokrat yang kurang melayani masyarakat secara adil dan merata itu tampak di hampir sebagian besar instansi yang ada di negara kita. Pendapat bahwa "Bekerja dengan rajin atau tidak rajin tetap mendapat gaji yang sama setiap bulan" ini turut mempertebal alasan keengganan para pegawai untuk bekerja dengan sebaik-baiknya.

Sementara itu, kelambanan dalam pelayanan umum tidak hanya disebabkan kurang baiknya cara pelayanan di tingkat bawah, namun ternyata masih banyak faktor yang mempengaruhi tata kerja dalam birokrasi. Sikap pandang organisasi birokrasi pemerintah kita, misalnya, terlalu berorientasi kepada kegiatan dan pertanggungjawaban formal. Penekanan kepada hasil kerja atau kualitas pelayanan sangatlah kurang, sehingga berimplikasi pada pekerjaan dalam organisasi menjadi kurang menantang. Dengan ditambah etos kerja yang 
buruk, maka jadilah suasana rutinitas yang semakin menggejala dan akhirnya aktivitasaktivitas yang dijalankan itu menjadi "counter productive".

Masalah kekakuan prosedur juga melanda institusi-institusi pemerintah, yang seharusnya melaksanakan aktivitas secara profesional. Birokrasi seolah-olah menjadi mahluk yang semakin gemuk, tetapi pada saat yang sama semakin lamban gerakannya. Dominasi birokrasi pada badan-badan usaha yang monopolistik itu tidak ditunjang dengan sistem manajemen dan efisiensi yang baik, sehingga tidak heran jika terlontar banyak ungkapan bahwa birokrasi kita merupakan sumber utama ekonomi biaya tinggi (hisg cost economic) yang mengurangi daya saing produkproduk kita. Hal ini antara lain disebabkan karena kurang adanya manajemen yang berdasarkan sasaran (management by objective) serta kaburnya tolok ukur untuk menilai prestasi.

Sebagaimana dikemukakan Sudarsono (1994 : 44) bahwa ketidakmampuan birokrasi menghasilkan jasa dengan mengolah sumbersumber yang efisien disebabkan dua hal. Pertama, karena tidak ada kompetisi. Dalam hal ini sebagian besar birokrasi sektor publik memegang monopoli atas barang dan jasa yang dihasilkan. Penyediaan jasa izin perdagangan, izin perindustrian, izin pertanahan, dan sebagainya, semua dilakukan oleh birokrasi sektor publik dengan monopoli yang penuh. Walaupun kini mulai banyak muncul jasa-jasa pelayanan swasta, misalnya rumah sakit, pendidikan, dan lain-lain. Ini tidak berarti bahwa fungsi monopoli birokrasi berakhir. Kedua, adanya gejala ketidaksempurnaan informasi (imperpect imformation) juga menyebabkan birokrasi tidak dapat mengelola informasi tentang permintaan barang-barang kolektif, misalnya pendidikan, jasa kesehatan, dan sebagainya dari masyarakat, baik tentang kualitas, kuantitas, maupun pelayanan sulit sekali didapat

Posisi dan jaringan kerja birokrat dapat menguasai informasi lebih banyak misalnya politisi atau kelompok-kelompok kepentingan (interest group) lainnya. Dengan penguasaan dan pengontrolan (sepihak) informasi inilah, secara teoritis birokrasi cenderung tidak dapat mengelola sumber-sumber daya secara efisien dan efektif.

\section{Etos Kerja Sebagai Nilai Dasar Moralitas}

Etos kerja merupakan nilai dasar moralitas yang dapat memberi dorongan mental maupun spiritual bagi seorang aparat birokrasi untuk dapat berprestasi dalam menjalankan profesinya. seperti nilai-nilai etika yang dikaitkan dengan etos kerja seperti rajin, bekerja, keras, berdisplin tinggi, menahan diri, ulet, tekun dan nilai-nilai etika lainnya bisa juga ditemukan pada masyarakat dan bangsa lain. Berikut adalah pengertian "etos" menurut Geertz yang dikutip Kumorotomo (1992 : 327) adalah : "sikap yang mendasar terhadap diri dan dunia yang dipancarkan hidup." Secara luas bangsa Indonesia sesungguhnya telah memiliki pijakan yang kuat untuk membina etos kerja yang dapat menunjang kemajuan. Disamping sikap hidup yang religius, bangsa Indonesia mempunyai Pancasila sebagai dasar nilai-nilai luhur yang tidak pernah kering. Konsep-konsep yang serupa dengan dasar-dasar etos kerja, telah kita miliki, seperti budi pekerti, gotong royong dan pengadilan, Kini tinggal bagaimana kita memanfaatkan gagasan-gagasan spiritual tersebut ke dalam gagasan-gagasan pembangunan.

Tujuan pembangunan hendaknya tidak terhenti dalam refleksi verbal, melainkan juga dalam aksi riil. Untuk melaksanakan aksi-aksi riil yang berkaitan langsung dengan kemajuan dan pembangunan dalam segala aspeknya, penyempurnaan dan pengembangan etos kerja para pejabat publik haruslah dilaksanakan tanpa henti. Bagi seorang pegawai negeri atau pejabat pemerintah, etos kerja yang baik bukan saja akan menghasilkan sikap-sikap produktif, seperti kerja keras, berperhitungan, jujur, dan hemat, tetapi juga akan menciptakan mekanisme kendali diri guna menghadapi berbagai persoalan dalam tugas kedinasan maupun mengatasi godaan dari luar.

Penggambaran di atas, mungkin terlalu idealis apabila kita melihat praktek pelaksanaan 
tugas-tugas layanan umum dalam birokrasi kita. Harus diakui bahwa tidak setiap pejabat memiliki kadar pemahaman tentang nilai pengabdian yang sama, dan setiap orang harus mencukupi kebutuhan keluarganya, disamping kewajiban untuk melayani kepentingan umum. Akan tetapi, justru dengan idealisme seperti itulah sesungguhnya kita masih akan bisa berharap banyak bagi pembangunan dan peningkatan kemakmuran rakyat melalui layanan dan tata kerja birokrasi.

Telah menjadi fenomena umum, bahwa kendala untuk meningkatkan etos kerja dalam organisasi publik ialah kurang mapannya ukuran untuk menilai produktivitas pegawai. Barangkali kita perlu mengingat lagi bahwa penekanan pada efektivitas dengan mengorbankan efisiensi sama sekali bukan gagasan yang baik dalam rangka peningkatan produktivitas. Yang diperlukan bagi organisasi-organisasi pemerintah sekarang ini adalah pandangan yang sistematis untuk mencanangkan program-program produktivitas tanpa menghilangkan daya tanggap terhadap kebutuhan masyarakat.

Setiap pejabat atau pegawai wajib mentaati prosedur, tata kerja, dan peraturanperaturan yang telah ditetapkan oleh organisasi pemerintah. Sebagai pelaksana kepentingan umum, para pejabat wajib mengutamakan aspirasi masyarakat dan peka terhadap kebutuhan-kebutuhan masyarakat. Sebagai manusia yang bermoral, pejabat selayaknya memperhatikan nilai-nilai etis dalam bertindak dan berperilaku. Dengan kata lain, seorang pejabat harus memiliki kewaspadaan profesional dan kewaspadaan spiritual. Kewaspadaan profesional berarti bahwa ia harus mentaati kaidah-kaidah teknis dan peraturan-peraturan sehubungan dengan kedudukannya sebagai seorang pembuat keputusan. Sedangkan kewaspadaan spiritual merujuk pada penerapan nilai-nilai kearifan, kejujuran, keuletan, sikap sederhana dan hemat, tanggung jawab, serta akhlak dan perilaku yang baik.
3. Etos Kerja Profesionalisme dalam Penyelenggaraan Birokrasi Pemerintahan

Dalam penyelenggaraan pemerintah menuju good governance tentunya perlu adanya dukungan sumber daya manusia yang memiliki kualitas sesuai bidangnya, agar dalam melaksanakan penyelenggaraan pemerintahan dapat berjalan dengan baik dan profesionalisme, apalagi dalam menghadapi persaingan dengan negara lain sumber daya manusia yang berkualitas sangat diperlukan, kalau tidak negara kita akan ketinggalan. profesionalisme dalam penyelenggaraan pemerintahan kan menjadi sebuah tuntutan yang sangat penting terkait dengan layanan birokrasi baik untuk internal administrasi pemerintahan maupun dalam memberikan layanan terhadap masyarakat. untuk menuju pemerintahan yang profesional, dalam birokrasi pemerintahan perlu adanya upayaupaya pemerintah dalam meningkatkan kualitas sumber daya manusia yang dimilikinya. Untuk mengetahui bagaimana ciri birokrasi yang semestinya dimiliki dalam menjalankan pemerintahan yang profesional, sebagai acauannya adalah salah satu ciri birokrasi ideal sebagaimana yang dikemukakan Max weber adalah bahwa birokrasi harus menunjukkan profesionalisme menuju efisiensi. Dengan kata lain, dapat dikemukakan profesionalisme adalah suatu ciri utama administrasi negara dalam masyarakat industrial dan masyarakat yang sedang berada dalam transisi ke arah era industri. Aparatur negara tentunya dituntut untuk memiliki keahlian dan kepiawaian dalam bidang spesialis tertentu dalam menjalankan roda pemerintahan, demikian dikatakan Glasser, Abelson dan Gorrison, yang dikutip Suryawikarta (1994: 42).

Dalam The American Heritage Dictionary yang dikutip oleh Nimran (1994 : 13), bahwa : "Profesionalisme merupakan suatu status, metode, karakteristik, atau standar tertentu untuk menghasilkan dan /atau ukuran bagi kualitas suatu karya, produk dan jasa yang dihasilkan oleh seorang yang profesional di dalam menjalankan tugas di bidangnya." Dalam hubungan ini, kualitas kerja yang prima, 
pelayanan yang memuaskan, jaminan ketepatan dan kecepatan waktu, kesetiaan dan kecintaan pada profesi adalah beberapa contoh ciri-ciri profesionalisme dalam sektor publik/bisnis dan kehidupan sehari-hari.

Dari uraian tersebut di atas, dapat dikemukakan permasalahan bagaimana menciptakan aparatur negara yang ahli dalam bidangnya masing-masing khsusunya dalam menjalankan birokrasi pemerintahan yang profesional, sehingga mampu memberikan pelayanan yang semakin meningkat baik jenis maupun mutunya kepada masyarakat, terutama menciptakan profesionalisme dalam konteks makro mengkait kepada pengembangan sumber daya manusia (human resources development), sedangkan dalam konteks mikro terkait dengan pengembangan karier. Pengembangan sumber daya manusia dan pengembangan karier bermuara pada upaya-upaya berbagai macam pendidikan dan latihan. Dengan demikian profesionalisme akan dicapai dengan melalui pendidikan dan latihan serta diperkaya dengan pengalaman berpraktek. Oleh karena itu, perlu disusun suatu program pendidikan dan latihan yang relevan dengan praktek dan profesi yang bersangkutan.

Untuk itu dalam rangka mengantisipasi pada masa mendatang, maka tuntutan kebutuhan masyarakat akan semakin bertambah yang harus ditanggapi oleh pemerintah. Hal ini berarti tuntutan pelayanan publik juga meningkat yang dapat dipenuhi oleh aparatur pemerintah yang profesional. Berdasarkan pengalaman selama ini, profesionalisasi aparatur ini kalah cepat dengan perkembangan tuntutan pelayanan publik, sehingga terdapat gejala-gejala ketidakpuasan masyarakat mengenai kinerja atau performance aparatur negara. Sikap aparatur di negara-negara berkembang dalam banyak hal bukan sebagai aparat penyelenggara negara dan kesejahteraan sosial yang melayani kepentingan masyarakat, akan tetapi sebaliknya. Kedudukannya lebih dirasakan sebagai suatu "privilage" ketimbang dalam kaitan dengan tugasnya sebagai suatu kewajiban. Sebab itu dalam tugasnya mereka bukan bersikap melayani, tetapi minta dilayani. Mereka tidak bertanya "Apa yang dapat saya lakukan untuk anda (what can I do for you ?". Akan tetapi sebaliknya :"Apa yang dapat anda lakukan untuk saya (what can you do for me) ?".

Untuk adanya peningkatan kualitas pelayanan kepada masyarakat, menurut Thoha (1997 : 7) haruslah dimulai dengan melakukan revitalisasi, restrukturisasi, dan reformasi (debirokratisasi dan deregulasi) terhadap birokrasi pemerintah. oleh karena itu birokrasi publik harus memikirkan langkah-lahkah seperti perampingan, penyederhanaan dan efisiensi, mulai dari jumlah kepegawaian dan kelembagaan organisasinya. Perampingan, penyederhanaan dana efisiensi dari pusat sampai daerah perlu dilakukan. Organisasi departemen yang kurang merangsang kinerja birokrasi yang efisien untuk berperan melayani masyarakat perlu dianalisis kemungkinan masih bisa dimanfaatkan atau tidak. Lebih dari itu, semua perilaku birokrasi mulai dari pimpinan sampai ke aparat yang paling bawah harus menunjukkan sikap jujur, bersih, berkarakter, profesional, mempunyai rasa malu dan mendahulukan melayani publik dengan sikap yang ramah, karena selama ini bahawa aparat birokrasi pemerintahan dalam memberikan layanannya selalu berbelit belit selain itu selalu memandang bahwa para parat birokrasi sering melakukan korupsi, kolusi dan nepotisme. Oleh karena itu, citra negatif birokrasi dan aparat perlu segera dipulihkan menjadi lebih positif dengan strategi pembangunan aparatur negara yang mengacu pada pembinaan dan pengembangan SDM secara profesional dan pembenahan manajemen pemerintahan

\section{Penutup}

Pembinaan dan pengembangan kualitas sumber daya manusia (SDM) aparat pemerintah atau birokrasi yang dilandasi etos kerja dan profesionalisme, merupakan hal yang mutlak diperlukan. Kendatipun bukanlah hal yang mudah menciptakan suatu sistem manajemen pelayanan yang baik, tetapi jalan pikiran yang sedang mengarah secara terencana untuk meningkatkan sumber daya manusia aparatur negara dan kemampuan manajemen sektor publik terus diupayakan, dan mau tidak mau pemerintah 
harus meningkatkan kualitas aparatur sumber daya manusianya hal tersebut untuk menciptakan sumberdaya manusia yang lebih profesional lagi terutama dalam penyelenggaran pemerintahan yang baik dan jika tidak indonesia akan ketinggalan oleh negara lain terkait dengan penyelenggaraan pemerintahannya.

Dengan etos kerja dan profesionalisme diharapkan dapat memperoleh tingkat pelayanan yang prima, seperti ketepatan waktu, keunggulan mutu, pengurangan biaya untuk memperoleh pelayanan, serta perlakuan yang semakin menempatkan masyarakat sebagai pihak yang memiliki martabat dan kedaulatan, semakin mendapat perhatian. Tentu banyak elemen yang harus ditata untuk menciptakan sebuah sistem yang pro-active seperti itu. Diperlukan sikap dan iklim yang kondusif untuk menumbuhkembangkan kinerja birokrasi pemerintah yang kreatif dan handal dengan dilandasi etos dan moral kerja yang tinggi. Pada konteks ini, makna profesionalisme aparatur dan manajemen pemerintahan menjadi hal yang urgen. Sebab aparat yang profesional, berwibawa, dan bertanggung jawab terhadap tugas-tugasnya dalam proses manajemen akan dapat mewujudkan kinerja organisasi serta menciptakan pelayanan yang lebih baik.

\section{DAFTAR PUSTAKA}

Kumorotomo, Wahyudi, 1992. Etika Administrasi negara, PT Raja Grafindo Persada, Jakarta.

Nimran, Umar. 1994. Strategi Pengambangan Profesionalisme Administrasi (Pokokpokok Pemikiran), dalam Temu Ilmiah Nasional Mahasiswa dan sarjana Administrasi Indonesia, UNIBRAW, Malang.

Riggs, Freud W. 1985 Administrasi Negaranegara Berkembang, Teori Masyarakat
Prismatis (terjemahan). CV Rajawali, Jakarta.

Santoro, Priyo Budi. 1993. Birokrasi Pemerintah Orde Baru (Perspektif Kultural dan struktural). PT Raja Grafindo, Jakarta.

Suryawikarta, Bay. 1994. Tanggung Jawab Administrasi Negara Dalam Meningkatkan Kinerja Pelayanan Melalui Penyempurnaan Kelembagaan dan SDM. LAN RI, Bandung.

Thoha, Miftah. 1997. Deregulasi dan Debirokratisasi Dalam Upaya Penin-katan Mutu Pelayanan Masyarakat. Makalah Dalam Seminar Nasional Persadi "Pembangunan Administrasi Dalam Repelita, 7 Maret 1977, Bandung. 